\title{
Correction to: Pharmacokinetic-Pharmacodynamic Modeling in Pediatric Drug Development, and the Importance of Standardized Scaling of Clearance
}

\author{
Eva Germovsek ${ }^{1,2}$ (D) Charlotte I. S. Barker ${ }^{1,3,4} \cdot$ Mike Sharland $^{3,4} \cdot$ Joseph F. Standing ${ }^{1,3}$
}

Published online: 17 December 2018

(c) The Author(s) 2018

\section{Correction to: Clin Pharmacokinet \\ https://doi.org/10.1007/s40262-018-0659-0}

The Open Access license, which previously read:

Open Access This article is distributed under the terms of the Creative Commons Attribution-NonCommercial 4.0 International License (http://creativecommons.org/licenses/ by-nc/4.0/), which permits any noncommercial use, distribution, and reproduction in any medium, provided you give appropriate credit to the original author(s) and the source, provide a link to the Creative Commons license, and indicate if changes were made.

Should read:

Open Access This article is distributed under the terms of the Creative Commons Attribution 4.0 International License (http://creativecommons.org/licenses/by/4.0/), which permits unrestricted use, distribution, and reproduction in any medium, provided you give appropriate credit to the original

The original article can be found online at https://doi.org/10.1007/ s40262-018-0659-0.

Eva Germovsek

eva.germovsek@farmbio.uu.se

1 Infection, Inflammation and Rheumatology Section, UCL Great Ormond Street Institute of Child Heath, University

College London, London, UK

2 Pharmacometrics Research Group, Department of Pharmaceutical Biosciences, Uppsala University, PO Box 591, 75124 Uppsala, Sweden

3 Paediatric Infectious Diseases Research Group, Institute for Infection and Immunity, St George's, University of London, London, UK

4 St George's University Hospitals NHS Foundation Trust, London, UK author(s) and the source, provide a link to the Creative Commons license, and indicate if changes were made.
Open Access This article is distributed under the terms of the Creative Commons Attribution 4.0 International License (http://creativeco mmons.org/licenses/by/4.0/), which permits unrestricted use, distribution, and reproduction in any medium, provided you give appropriate credit to the original author(s) and the source, provide a link to the Creative Commons license, and indicate if changes were made. 